\title{
THE RIGHT TO JUDICIAL REVIEW OF DEPORTATION ORDERS UNDER THE ADMINISTRATIVE PROCEDURE ACT*
}

Aliens are currently being expelled from the United States at a rate of more than 720,000 per year. ${ }^{1}$ Although the vast majority of these leave under volut1tary procedures, ${ }^{2}$ the forcible expulsion of other thousands ${ }^{3}$ is made to depend upon delicate factual findings by Immigration officials ${ }^{4}$ that the alien is in one of

\footnotetext{
*Heikkila v. Barber, 73 Sup. Ct. 603 (1953).
}

1. In the year ended June 30,1952 , a total of 723,959 aliens were deported or de* parted voluntarily from the United States. INM. \& NAT. SERv. ANN. REp. table 24A (1952).

2. Under the immigration laws in effect prior to the Immigration and Nationality Act of 1952, 66 Stat. 163 (1952), 8 U.S.C.A. \& 1101 et seq. (Supp. 1953), the Attorney General had authority to permit certain deportable aliens being proceeded against to depart voluntarily from the United States to any country of their choice, in lieu of formal deportation. 39 Stat. 889 (1917), as amended, 8 U.S.C. $\$ 155$ (c) (1) (Supp. 1952). The number of aliens departing voluntarily "under proceedings" in the year ended June 30, 1952, was 703,778. I IMM. \& NAT. SERV. REP. table 24A (1952). The large number of aliens expelled and the commensurately large number of voluntary departures is to a considerable extent a result of the great number of Mexican illegal entrants coming into the United States. Id. at 34, 35. For the regulations governing voluntary departure prior to the Act of 1952, see 8 CODE FED. REGs. $\$ \S 150.11,150.11 \mathrm{a}, 150.11 \mathrm{~b}$ (1949), and 8 CODE FED. REGS $\$ \S 150.3,152.1$ (Supp. 1951). See also the discussion of the methods employed by the Immigration and Naturalization Service to carry out the policy of voluntary departures. INIM. \& NAT.,SERv. ANN. Rep. 37 (1952). For a discussion of voluntary departure provisions of the Act of 1952, see Recent Developments in the Lazu-Immigration \& Naturalization, 66 HARv. L. Rev. 643, 688-9 (1953).

3. In the year ended June $30,1952,20,181$ aliens were formally deported. IMM. \& NAT. Serv. AnN. Rep. table 24A (1952).

4. The immigration laws prior to the passage of the Act of 1952 provided simply that a deportable alien "shall upon the warrant of the Attorney General be taken into custody and deported." 39 STAт. 889 (1917), as amended, 8 U.S.C. \$ 155(a) (1946). The procedures involved in deportation were prescribed by administrative regulations within bounds set by judicial requirements of due process. The rules regulating these procedurcs are set forth in 8 CoDE FED. ReGs. §§ 150, 151 (Supp. 1951). For a resumé of the procedures before 1952, see Werner, Expulsion of Aliens From the United States, 9 IMM. \& NAT. SERv. MonthLy REv. 114 (1951); and for an exposition of the rules under the Act of 1952 with references to former procedures, see Developments in the Late-Immigration and Nationality, 66 HARv. L. REv. 643, 690-7 (1953). 
the deportable categories defined by Congress in the immigration laws." Court review of these findings is sought annually by hundreds of designated deportees."

Prior to the passage of the Administrative Procedure Act in 1946, there were two methods by which aliens could question the validity of deportation proceedings in the courts. Where the deportee contested his status as an alien, or claimed eligibility for citizenship, the courts permitted him to seek judicial examination of his classification in an action for declaratory judgment. ${ }^{8}$ But where citizenship was not in issue, the alien could olstain review

5. 39 Stat. $\$ 89$ (1917), as amended, \& U.S.C. \$ 155 (Supp. 1952); 10 St.1T. 1012 (1918), as amended, S U.S.C. $\$ 137$ (Supp. 1952); 41 ST.IT. 593 (1920), as amcnded, 8 U.S.C. \$ 157 (1946); 43 Stat. 162 (1924), as aniended, \& C.S.C. \$ 214 (1946). The following table indicates the number of aliens deported from the Cnited States for eause in the years ended June $30,1949,1950,1951$, and 1952:

\begin{tabular}{lrrrr}
\multicolumn{1}{c}{ Caise } & 1952 & 1951 & 1950 & 1949 \\
All causes & 20,181 & 13,544 & 6,623 & 20,010 \\
Criminals & 778 & 1,036 & $\mathbf{7 9 0}$ & 1,024 \\
Immoral classes & 50 & $\mathbf{6 7}$ & $\mathbf{5 3}$ & $\mathbf{7 6}$ \\
Violators of narcotics laws & 40 & $\mathbf{6 2}$ & $\mathbf{5 5}$ & $\mathbf{7 0}$ \\
Miental or physical defectives & 56 & 45 & $\mathbf{5 3}$ & $\mathbf{5 2}$ \\
Previousily excluded or deported & $\mathbf{5 3 9}$ & 940 & $\mathbf{5 5 3}$ & $\mathbf{3 , 8 1 5}$ \\
Remained longer than authorized & 4,469 & 3,289 & 1,661 & 1,379 \\
Entered without proper documents & 9,636 & $\mathbf{5 , 3 2 2}$ & 1,352 & 995 \\
Abandoned status of admission & 475 & 298 & 224 & $\mathbf{3 2 9}$ \\
Entered without inspection or by & & & & \\
$\quad$ false statements & 3,706 & 2,293 & 1,734 & 12,094 \\
Likely to become public charges & 24 & 14 & 38 & 20 \\
Subversive or anarchistic & 31 & 18 & 6 & 4 \\
Miscellaneous & 377 & 160 & 109 & 149
\end{tabular}

From I IrM. \& NAt. SERv. ANN. REP. 36 (1952).

6. In the year ended June 30,1952 , the courts disposed of 319 applications iur writs of habeas corpus by aliens seeking review of deportation orders. Of this total 14 writs were sustained, 221 dismissed, and 84 withdrawn. At the end of the year $\mathbf{5 2}$ writs vere pending. Inim. \& NAT. SeRv. ANN. Rep. table 48 (1952).

7. 60 Stat. 237 (1946), as amended, 5 U.S.C. $\$ \$ 1001$ et seq. (Sunp. 1952).

S. Perkins v. Elg, 307 U.S. 325 (1939) (claim of citizenship). The Nationality Act of 1940,54 STAT. 1171,8 U.S.C. $\$ 903$ (1946), made express provision for individuals within the United States or abroad to bring declaratory judgment actions to settle the issue of their citizenship. McGrath v. Kristensen, 340 U.S. 162 (1950) (eligibility for citizenship). But see the treatment of the claim of eligibility for citizenship in the Kristensen case by the Court of Appeals for the District of Columbia. 179 F.2d 796 (D.C. Cir. 1949). See Note 12 infra. See also a discussion of the implications of the Supreme Court's decision in the Kristensen case in Note, 51 CoL. L. RE. 10:4t (1951).

The claim of citizenship has always received special treatment. In habcas corpus proceedings the question of citizenship must be tried de novo to satisfy the requirements of due process of law. Ng Fung Ho v. White, 259 U.S. 270 (1922). But, while the turden of proving alienage is on the Government-United States ex rel. Bilokumsly v. Tod, 263 U.S. 149 (1923) ; United States ex rol. Bishop v. Watkins, 159 F.2d 505 (2d Cir.), ccrt. denied, 331 U.S. 839 (1947) -, a person arrested on a warrant of deportation is not protected by a presumption of citizenship comparable to the presumption of innceence in criminal cases. United States ex rel. Bilokumshy v. Tod, supra, at 154 ( failure tu tal:e stand to assert citizenship held sufficient to support the inference of a lack of citizenship). 
of a deportation order only by applying for a writ of habeas corpus. ${ }^{0}$ Section 10 of the Administrative Procedure Act, ${ }^{10}$ however, made provision for judicial review of final actions" ${ }^{11}$ of administrative agencies by "any applicable

9. United States $e x$ rel. Vajtauer v. Commissioner, 273 U.S. 103 (1927); Fong Yum Ting v. United States, 149 U.S. 698 (1893) ; see Bridges v. Wixon, 326 U.S. 135, 167 (1945) (dissent).

10. "Except so far as (1) statutes preclude judicial review or (2) agency action is by law committed to agency discretion-

"(a) Right of Review.-Any person suffering legal wrong because of any agency action, or adversely affected or aggrieved by such action within the meaning of any relevant statute, shall be entitled to judicial review thereof.

"(b) FoRM AND VENUE of ACtron.-The form of proceeding for judicial review shall be any special statutory review proceeding relevant to the subject matter in any court specified by statute or, in the absence or inadequacy thereof, any applicable form of legal action (including actions for declaratory judgments or writs of prohilitory or mandatory injunction or habeas corpus) in any court of competent jurisdiction. Agettcy action shall be subject to judicial review in civil or criminal proceedings for judicial enforcement except to the extent that prior, adequate, and exclusive opportunity for stch review is provided by law.

"(c) Reviewable Acts.-Every agency action made reviewable by stattute and every final agency action for which there is no other adequate remedy in any court shall be subject to judicial review. Any preliminary, procedural, or intermediate agency action or ruling not directly reviewable shall be subject to review upon the review of the final agency action....

“. . .

“(e) SCOPE of REviEw.-So far as necessary to decision [sic] and where presented the reviewing court shall decide all relevant questions of law, interpret constitutional and statutory provisions, and determine the meaning or applicability of the terms of any agency action. It shall (A) compel agency action unlawfully withheld or untreasonably delayed; and (B) hold unlawful and set aside agency action, findings, and conclusions found to be (1) arbitrary, capricious, an abuse of discretion, or otherwise not in accordance with law; (2) contrary to constitutional right, power, privilege, or immunity; (3) in excess of statutory jurisdiction, authority, or limitations, or short of statutory right; (4) without observance or procedure required by law; (5) ullsupported by substantial evidence in any case subject to the requirements of sections 7 and 8 or otherwise reviewed on the record of an agency hearing provided by statute; or (6) unwarranted by the facts to the extent that the facts are subject to trial de novo by the reviewing court. In making the foregoing determinations the courts shall review the whole record or such portions thereof as may be cited by any party, and due account shall be taken of the rule of prejudicial error." 60 STAт. 243 (1946), 5 U.S.C. \& 1009 (1946).

11. The exhaustion of administrative remedies is required before judicial review becomes available. 60 Stat. 243 (1946), 5 U.S.C. $\& 1009$ (c) (1946). See note 10 supra. For application of this requirement, see United States $c x$ rel. Trinlcr v. Carusi, 166 F.2d 457, vacated on other grousts, 168 F.2d 1014 (3d Cir. 1948) (petition for review of a deportation order issued, but not served; held: administrativo process at an end for purposes of "finality"); Kristensen v. McGrath, 179 F.2d 796 (D.C. Cir. 1949) (declaratory and injunctive relief sought before deportation order issued; held: administrative remedies exhausted for purposes of "finality"); Scholnick v. Clark, 81 F. Supp. 298 (D.D.C. 1948) (injunctive and declaratory relicf sought during early stage of deportation proceedings; held: relief unavailable because administrative remedies not exhausted). But cf. Yanish v. Wixon, 81 F. Supp. 
form of legal action," and excepted from its coverage only those argency actions which Congress had exempted from judicial review, and those which were, by law, committed to agency discretion. Three United States Courts of Appeals, in applying the Act, granted Section 10 review in deportation cases where citizen status was not an issue on appeal. ${ }^{12}$ These decisions denied that the terms of the Immigration Act of $1917^{13}$-which made the Attorney General's order "final" in such matters 14 - had placed deportation proceedings within the class of actions excepted from the review available under Section 10.15 Since judicial review by habeas corpus had regularly been permitted in deportation cases, the courts reasoned that the immigration statute failed to evidence any intent to preclude full Section 10 review of expulsion findings.

In Heikkilav. Barbcr, ${ }^{10}$ the Supreme Court took issue with the holdings of all three Courts of Appeals, ${ }^{17}$ and once again confined the review of deportation

499 (N.D. Cal. 1948), revid on other grounds sub nom. Lanish v. Barber, 181 F.2d 492 (9th Cir. 1950) (administrative remedies need not be exhausted where jurisdiction of Immigration authorities is challenged). Where declaratory relief is suught to dutermine an alien's status, administrative remedies must be exhaustcd. Kristınsen v. MIcGrath, 340 U.S. 162, 169 (1950). They must also be exhausted in habeas corpus proceedings. United States $e x$ rel. Zdunic v. Uhl, 144 F.2d 286 (2d Cir. 1944); Yialoumis v. Hall, 83 I. Supp. 469 (E.D. Va), dismissed as moot, 177 F.2d S04 (fth Cir. 1949).

12. Prince v. Commissioner, 185 F.2d 578 (wth Cir. 1980) (petition for review); United States ex rel. Trinler v. Carusi, 166 F.2d 457, aracalcd on other grosmds, 163 F2d 1014 (3d Cir. 1948) (petition for review); Kristensen v. MrGrath, 179 F.2d 790 (D.C. Cir. 1949) (declaratory and injunctive relief). The Second Circuit avoided the question when it appeared as a possible issue in Azzolini v. Watlins, 172 F.2d $\$ 97$ (2.1 Cir. 1949). The court held that it was unnecessary to decide whether Section 10 of the APA applied, since the petition for review was plainly without mcrit. See the similar treatmicnt of a petition for review in Alves v. Shaughnessy, 107 F. Supp. 43 (S.D.N.Y. 1952). Contra: Valenti v. Clark, 83 F. Supp. 167 (D.D.C. 1949).

In the Kristensen case, sipra, the circuit court held that a declaratory judgment action under the Administrative Procedure Act was an appropriate method to seek review of the Attorney General's refusal to suspend deportation on the sole ground that the alien was ineligible for citizenship. The alien sought declaration by the court of his eligibility. The Supreme Court, while upholding the right of the alien to seek dcelaratory relief, did so on the grounds that "[W] Where an oficial's authority to act depends upen the status of the person affected, in this case eligibility for citizenship, that status, when in dispute, may be determined by a declaratory judgment procecding after the exhaustion of administrative remedies." Kristensen v. MIcGrath, 340 U.S. 102, 169 (1950). The Court found it unnecessary to consider the applicability of the Administrative Procedure Act.

13. 39 STAT. $8 \$ 9$ (1917), 8 U.S.C. $\$ 155$ (1946).

14. "In every case where any person is ordered deported from the United States under the Provisions of this Act, or of any law or treaty, the decision of the Attomey General shall be final." Id. § 155 (a).

15. See note 10 supra.

16. 73 Sup. Ct. 603 (1953).

17. The Supreme Court rejected two previous opportunities to pass upon the question of the applicability of the APA to deportation proceedings. See note 12 susra; and see also Brief for Petitioner, pp. 23-6, Brief for Respondents, pp. 18-40, Reply Brief for 
orders, where citizenship status or eligibility for citizenship was not in question, to habeas corpus proceedings. Heikkila, relying on Section 10 of the Administrative Procedure Act, had sought review of the validity of a deportation order against him and had asked for injunctive and declaratory relicf. The Court found that the term "final," as used in the Immigration Act of 1917 to describe the Attorney General's decisions, had acquired a definitive meaning from immigration statutes enacted in the twenty-five years preceding 1917; and that under the judicial interpretation given "final," the 1917 Act precluded judicial review except so far as required by the Constitution. ${ }^{18}$ Thus, the majority initially seems to indicate that since Section 10 is applicable by its own terms " $[\mathrm{e}] \mathrm{xcept}$ so far as ... statutes preclude judicial review," it cannot in deportation cases expand the review previously confined to habeas corpus. ${ }^{18}$

The Court would have been logically justified in resting on its conclusion at this point. By treating the ambiguous "except so far as" clause as merely perpetuating existing restrictions on the type of review available, the Court could have reached a reasonable interpretation of the statute. But the majority went further. It declared that the limited nature of habeas corpus review was in no sense "judicial review" as that term was used in the APA; therefore, the APA did not apply at all to deportation proceedings. ${ }^{20}$ In a dissent ${ }^{21}$ based upon the legislative history of the APA, Justices Frankfurter and Black seized upon this reasoning. Claiming that the majority had grossly underestimated the broadly remedial purposes of the Administrative Procedure Act, they asserted that the majority had placed too narrow an interpretation upon "judicial review" as used in that Act; and they concluded that the Act, in fact, did cover the proceedings of the Immigration authorities. ${ }^{22}$ The dissenters suggested, however, that even though the forms of Section 10 review should be available to an alien subject to the 1917 Act, the scope of review is restricted within the limits previously available under habeas corpus. ${ }^{\text {at }}$

Petitioner, pp. 10-16, Martinez v. Neely, 73 Sup. Ct. 345 (1953). The Court affirmcd without opinion the Seventh Circuit's decision, 197 F.2d 462 (7th Cir. 1952), which had expressly avoided the issue.

18. "Read against this background of a quarter of a century of consistent judiclal interpretation, $\S 19$ of the 1917 Immigration Act, 39 Stat. 890 clearly had the effect of precluding judicial intervention in deportation cases except insofar as it was required by the Constitution." Heikkila v. Barber, 73 Sup Ct. 603, 606 (1953).

19. "Clearer evidence that for present purposes the Immigration Act of 1917 is a statute precluding judicial review would be hard to imagine. Whatever view be taken as to the breadth of $\S 10$ of the Administrative Procedure Act, the first exception to that section applies to the case before us. The result is that appellant's rights were not enlarged by that Act. Now, as before, he may attack a deportation order only by habcas corpus." Ibid.

20. Id. at 607 .

21. Ibid.

22. Id. at 607,608 .

23. Id. at 608 . 
In limiting the review available in deportation cases to habeas corpus proceedings, the majority seems to have given reasonable effect to the language of Section 10. And there is no practical difference between the results that would accrue from their initial reliance on the "except so far as" clause and those stemming from their final conclusion that there never was "judicial review" of such orders. As the minority points out, however, the majority's basic conclusion is unfortunate on a policy level: it fails to give any effect to the acknowledged remedial purposes of the APA. But the dissenters only in part meet this criticism. They hold that the Attorney General's decisions under the Immigration Act of 1917 were in fact reviewed by the courts in the APA sense; that according to the legislative history of the Act the term "judicial review" was not intended to be given a technical construction." Yet, while they reject the final conclusion of the majority and find that deportation proceedings fall within the APA, they seem themselves to become ensnared in the "except so far as" language, since they limit the scopc of review. There is nothing in the language of Section 10 to suggest that the "except so far as" clause is to have any different application to the form of review available under 10 (b) than to the scopo of review provided for in $10(\mathrm{e}) .^{25}$ If, as the minority implies, Section $10(\mathrm{~b}) \mathrm{may}$ be involed in full upon a finding that judicial review was previously available, then the "excepting clause" would seem to mean that the review provisions of the APA will be inapplicable only where statutes preclude all judicial review. Since in their view this is not so in the case of deportation proceedings, full application of the APA would be required. Although such a position is at least arguable, the minority's ultimate refusal to permit review of scope beyond that available in habeas corpus contradicts its own logic and makes any attempt at conclusive analysis of the minority opinion impossible..$^{20}$

The effect of the Heikkila decision, under either the majority ur minority view, is to create two distinct and anomalous classes of alien deportees. The

24. The very fact of its inclusion in Section 10 of the APA, see note 10 stopra, seems to indicate that Congress considered habeas corpus "judicial review." In no frart of the legislative history of the APA is a distinction made between habras corpus review and other forms of review. See Sex. Doc No. 24s, 79th Cong., 2d Sess. 36-7, 212, 276, $325-6,369$ (1946).

25. See, however, note 26 infra. The majority in Heiklila, while refusing to pass un the question, 73 Sup. Ct. 603, 607 n.12 (1953), appears to have felt that if Section 10 were applicable at all, the full scope of its review would be accorded despite previous habeas corpus restrictions. Id. at 606, 607 .

26. It might be possible to argue that the "except so far as" clause works a different effect on $\$ 10(\mathrm{~b})$ than on $\$ 10(\mathrm{e})$ because of the provision in $10(\mathrm{~b})$ that the form of review shall be any "special statutory review . . or, in the absence or inodcultocy" thereof, any applicable form of legal action." (Emphasis supplied.) See note 10 stspr. The dissenters in Heikkila note the inconvenience of the habeas corpus requirement that the alien be in custody before he can challenge a deportation order. 73 Sup. $\mathrm{Ct}_{\text {. }} 603,608-9$ (1953). This "inconvenience" could be interpreted as an "inadequacy" of habeas corpus review as that term is used in $\S 10(b)$. Though habeas corrus is not a "special statutory review," the Court has read constitutional requirements into the immigration statute for 
1917 law has been replaced by the Immigration and Nationality Act of 1952.27 And in new deportation actions instituted under that statute, the full scope of review available under Section 10 will undoubtedly obtain.28 The Supreme Court declared in Heikkila that it would study the legislative history of every congressional statute to determine whether judicial review under the Administrative Procedure Act was intended. ${ }^{20}$ And the history of the 1952 Act clearly shows that intent: both Senator McCarran and Representative Walter, sponsors of the bill, announced in congressional debates that Section 10 of the APA would apply to deportation proceedings under the new Act, and that the Attorney General's orders would possess "finality" only in the administrative sense. $^{30}$ But the provisions of the new Act do not apply to actions commenced

the purposes of the APA before. See note 43 infra. Thus, it is possible to argue that while the "except so far as" clause works its limitation on all subsections of $\$ 10$, it is itself subject to the language of $10(\mathrm{~b})$ and therefore that the alien is not limited to habeas corpus review because that form of "statutory" review is "inadequate."

27. 66 Stat. 163 (1952), 8 U.S.C.A. \$§ 1101 et seq. (Supp. 1953).

28. See discussion in text at notes $42-47$ infra.

29. 73 Sup. Ct. 603,605 (1953).

30. The Immigration and Nationality Act of 1952, 66 STAT. 163 (1952), 8 U.S.C.A. $\$ 1101$ et seq. (Supp. 1953), provides, as did its predecessor, the Act of 1917: "In any case in which an alien is ordered deported from the United States under the provisions of this chapter or of any other law or treaty, the decision of the Attorney General shall be final." 66 Stat. 208, (1952), 8 U.S.C.A. $\$ 1252$ (b) (Supp. 1953). This provision caused concern among some members of Congress who feared that judicial review of deportation orders was thereby precluded. See statements of Senator Benton, 98 CoN(. Rec. 5113 (1952); Senator Welker, id. at 5421; Representative Heller, id. at 4311. Senator Lehman proposed an amendment which would have expressly made the provisions of the Administrative Procedure Act applicable to "all proceedings relating to the exclusion or expulsion of aliens." Id. at 5427-8. And Senator Morse offered an amendment which would make a declaratory judgment action available to review deportation or exclusion proceedings. Id. at 5781 . But both of these amendments were defeated. In the House, Representative Meader offered an amendment which would have subjected deportation orders to "review by any court of competent jurisdiction." Id. at 4414-16. That, too, met defeat. However, these amendments were defeated on the ground that judicial review already existed for deportation proceedings and because of a reluctance to cxpand review of exclusion proceedings. In response to the Meader amendment, Representative Walter explained what was meant by the "finality" provision of the new Act. "Now we come to this question of the finality of the decision of the Attorney Gencral. That language means that it is a final decision as far as the administrative branch of the government is concerned, but it is not final in that it is not the last remedy the allen has. Section 10 of the Administrative Procedures Act [sic] is applicable. From that decision an appeal lies in the courts. If there is not a final administrative decision, then these aliens will go from one administrative body to another, seeking relief, bectuse they do not want a final ajudication. ...

"In view of the fact that every person who is ordered deported has all of these administrative processes available, plus an appeal to the court, plus a right to at writ of habeas corpus, I cannot conceive of a case where any injustice would be done by some capricious or arbitrary administrator.

"I would like to remind the gentleman of one thing, that Senator MLCApren, who sat in these hearings, and in the preparation of this bill, and I, were both comunended by 
prior to its passage. ${ }^{31}$ Since many deportation proceedings under the 1917 Act are still pending and many such deportation orders are outstanding, 32 aliens proceeding according to the old Act will ply a different road in search of relief than their counterparts under the present statute.33

Significant differences exist between the scope and form of review available under habeas corpus proceedings and the scope and form available under the unrestricted application of Section 10 of the Administrative Procedure Act. Deportation orders would be subject to a broader review under the APA than is now required in habeas corpus actions. The writ of habeas corpus traditionally issues only where the alien can prove he has been denied

the American Bar Association because of the work we did in providing for judicial review from a decision of an administrative agency. We have been very zealous to sce that the philosophy underlying that act is embodied in this measure." Id. at 4416.

Senator MicCarran echoed this explanation. "Why is it, Mr. President, that the opponents of this measure repeatedly assert that my bill violates the provisions of the Administrative Procedure Act in deportation proceedings when a perusal of the bill would convince any fair-minded man that the bill is 100 percent within the framevork of the Administrative Procedure Act, which, incidentally, I snonsored and authored in the Senate. Mr. President, no Senator is more jealous of the provisions of the Administrative Procedure Act than is the senior Senator from Nevada; and I say to the Senate that the omnibus immigration bill, S.2550, is completely within the frameworl: of the Administrative Procedure Act." Id. at 5329. See also, explanatory statements by Representative Walter, $i d$. at 4302,4429 , and the statement of the House managers, appended to the Conference Report on the Act. H.R. REP. No. 2096, S2d Cong., 2d Sess. 127 (1952). It is also indicative of congressional intent to provide judicial review that $\$ 242$ (c) of the Act, 66 STAT. 208 (1952), S U.S.C.A. \$ 1252(c) (Supp. 1953), specifically recognizes such review.

31. 66 Stat. 280 (1952), Pub. L. No. 414, \&2d Cong., 2d Sess. $\$ 405$ (June 27, 1952).

32. On June $30,1952,8,505$ unexecuted orders of deportation vere outstanding. 3,183 of these had been outstanding 6 months or less, while 5,322 had bcen outstanding over six months, some for years. Irrar. \& NAT. SErv. Axw. Rep. 37 (1952). On Oetobar 1, 1952 there were 4,959 unexecuted orders of deportation which had been outstanding in

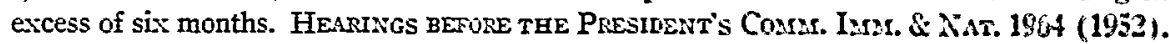

It is possible that many years after the passage of the 1952 Act, the courts will still be dealing with deportation orders issued under the Act of 1917. Sce Cnited States cx rel. Adamantides v. Neelly, 191 F.2d 997 (7th Cir. 1951) (15 years from service of warrant of deportation to court review of deportation order); Prince v. Cummissioner, 185 F.2d 578 (6th Cir. 1950) (9 years from service of warrant of deportatiun to court review of deportation order); Kristensen v. MfCGrath, 179 F.2d 796 (D.C. Cir. 1949) ( 8 years from service of warrant of deportation to court review of procecdings); Vergas v. Shaughnessy, 97 F. Supp. 335 (S.D.N.Y. 1951) (11 years from service of warrant of deportation to court review of deportation order).

33. Confronted with convincing evidence of legislative purnose and in view of the express interpretation of "finality" as "administrative finality" the courts can ba expacted to grant full APA review to post-1952 deportees, while limiting pre-1952 aliens to the Heikkila-restricted remedy of habeas corpus. Since the 1952 Act's provision that the Attorney General's actions shall be "final" is not an attempt to limit judicial review, $\$ 10$ of the APA, applicable except so far as statutes preclude judicial review, applies in full to the Act. 
due process of law. ${ }^{34}$ Such a showing can be made by his demonstrating that the Immigration authorities acted outside of the scope of their statutory authority, ${ }^{35}$ or that the procedure adopted to arrive at a decision was unfair, ${ }^{40}$ or that there was a lack of evidence to support the decision. ${ }^{37}$ But in all cases the inquiry is limited to the constitutionality of agency action. ${ }^{38}$ To comply with the requirements of due process, there must at least be sufficient evidence to show that the action of the Attorney General was not arbitrary or unreasonable. ${ }^{30}$ In recent years some courts have expanded their inquiry in habeas corpus proceedings and have required a showing of "substantial" evidence to support deportation orders. ${ }^{40}$ The verbal formula still accepted by the Supreme Court, however, permits the decisions of Immigration authorities

34. Heikkila v. Barbar, 73 Sup. Ct. 603,606 (1953) ; see also the dissent of Donglas, J., on other grounds, in Ludecke v. Watkins, 335 U.S. 160, 185 (1948).

35. See, e.g., Mahler v. Eby, 264 U.S. 32 (1924) (order of deportation based on reasons not specified by Congress void); Gegiow v. Uhl, 239 U.S. 3 (1915); Gonzales v. Williams 192 U.S. 1,15 (1903).

36. Wong Yang Sung v. McGrath, 339 U.S. 33, modificd, 339 U.S. 908 (1950); Chin Yow v. United States, 208 U.S. 8 (1907); Japanese Immigrant Case (Yamatayat v. Fisher), 189 U.S. 86 (1903). As an aspect of a fair hearing, due notice to the alien of the charge against him is required. United States $e x$ rcl. Tisi v. Tod, 264 U.S. 131 (1924).

37. See, e.g., Kessler v. Strecker, 307 U.S. 22 (1939); Scholnick v. Clark, 81 11. Supp. 298 (D.D.C. 1948).

38. See Yiakoumis v. Hall, 83 F. Supp. 469, 472 (E.D. Va.), dismissed as moat, 177 F.2d 804 (4th Cir. 1949): "In every such instance [habeas corpus review] the writ has gone no further than to ascertain whether a person in custody is held under authority of law ... and to determine whether or not the deportation order was reached through procedures affording due process of law. It is a review of the constitutionality of the custody and expulsion."

In Kessler v. Strecker, 307 U.S. 22 (1939), the Supreme Court states the traditianal formula for review: "If the hearing was fair, if there was evidence to support the finding of the Secretary, and if no error of law was committed, the ruling of the Department must stand and cannot be corrected in judicial proceedings." Id. at 34. The courts need inquire into these standards only to see that a constitutional minimum of protection is maintained. See also United States ex rel. Tisi v. Tod, 264 U.S. 131 (1924). Thus there is no showing of a lack of due process merely by establishing that the decision of the agency is wrong or that incompetent evidence was received and considered. United States ex rel. Vajtauer v. Commissioner, 273 U.S. 103, 106 (1927). But for an indication of how far courts will sometimes go into the facts, see U.S. exr rcl. Castro-Louzan v. Zimmerman, 94 F. Supp. 22 (E.D. Pa. 1950) (lack of fair hearing where unbefriended alicu, unable to speak English and without funds, was merely given the opportunity to use telephone to obtain an attorney) ; Bridges v. Wixon, 326 U.S. 135 (1945) (Court appears to substitute its own judgment for that of the immigration authorities). See also Note, 49 CoL. L. REv. 73, 85-7 (1949).

39. United States ex rel. Tisi v. Tod, 264 U.S. 131, 133-4 (1924).

40. See, e.g., United States ex rel. Adamantides v. Neelly, 191 r.2d 997, 1000 (7th Cir. 1951) ; United States $c x$ rol. Jankowski v. Shaughnessy, 186 F.2d 580, 582 (2d Cir. 1950) ; Schoeps v. Carmichael, 177 F.2d 391, 395 (9th Cir. 1949), cert denicd, 339 U.S. 914 (1950); United States e.r rel. Schlimmgen v. Jordan, 164 F.2d 633, 634 (7th Cir. 1948). 
to be upheld where "some" or "any" evidence or simply "evidence" supports their conclusion. ${ }^{41}$ Even where "substantial evidence" standards are applied in habeas corpus review, the Supreme Court's decision in Univirsal Camora Corp. v. National Labor Relations Board ${ }^{22}$ indicates that the APA requirement of "substantial evidence . . . on . . . the whole record" 13 imposes a wider scope of review than the traditional "substantial evidence" test applied in habeas corpus proceedings. Under an unrestricted application of APA, the courts are instructed to weigh evidence supporting the Government's action against evidence offered by the alien." Under labeas corpus pro-

41. Kessler v. Strecker, 307 U.S. 22. 34 (1939) (evidence); Unitcd States cr rel. Vajtauer v. Commissioner, 273 U.S. 103, 106 (1927) (some evidence and any cvidunce used interchangeably); Bridges v. Wixon, 326 U.S. 135, 149 (1945) (sonte evidence); sec Ludecke v. Watkins, 335 U.S. 160, 185, 187 (1948) (dissent uyon uther grusuls of Douglas, J., iterating a some evidence test). Dissenting in the Bridges case, strtro, (hiei Justice Stone states that the courts had always been satisficd if evidente of "any probative value" was available to support the decision of administrative agencies. 32, U.S. at 167. His opinion indicates the amount of evidence that the Cuurt required as a minimum to satisfy constitutionality before the Bridgos case. "With incrcasing frequency this court is called upon to apply the rule, which it has followed for many yours, in depurtation cases as well as in other reviews of administrative procedings, that when there is evidence more than a scintilla, and not unbelieveable on its face, it is for the administrative officer to determine its credibility and weight. . . . We connot rightly rejest the administrative findings here and accept, as we do almost each week, particularly in our denials of certiorari, the findings of administrative agencies which rest on the tunuous support of evidence far less persuasive than the present recurd presents." Id. at 173.

42. 340 U.S. 474 (1951).

43. 60 STAT. 243 (1946), 5 U.S.C. $\$ 1009$ (e) (1946). While there are limitations placed upon the applicability of the "substantial evidence" requirement in $\$ 10(\mathrm{e})(5)$, these limitations would not seem to pertain to deportation proceedings under the immigration acts. The Act of 1917 is not subject to the requirements of $\$ \$ 7$ and $\$$ of the APA, see note 52 infra, nor is there an express statutory requirement of a hearing with a determination of deportability on the record. See note 4 sispra. But the Supreme Court has held that a hearing with a determination on the record is demanded by the Constitution, and the Court reads this constitutional requirement into the statute. The Court finds that the APA's requirement of a "statutory" provision for a hearing is satisfied by the "more than statutory" requirement imposed by the Constitution. Wung Yang Sung v. MIcGrath, 339 U.S. 33, modificd, 339 U.S. 908 (1950). The Act of 1952 malies specific statutory provision for determination of deportability on the record made at a hearing. 66 StAT. 208 (1952), \& U.S.C.A. $\$ 1252$ (b) (Supp. 1953).

44. "The substantiality of evidence must take into accuunt whatever in the record fairly detracts from its weight. This is clearly the signiticance of the requirement ... that the courts consider the whole record. Committee reports and the adogtion in the Administrative Procedure Act of the mirority views of the Attorney General's Committee demonstrate that to enjoin such a duty on the reviewing court vas one of the important purposes of the movement which eventuated in that enactment" Univercal Camera Corp. v. National Labor Relations Board, 3:0 U.S. 474, 4:S (1951). The Court concedes that Congress by the use of these terms has expressed a "mood" and not a "body of rigid rules assuring sameness of application." Id. at 477. But beeause the change is so "elusive," the court warns, it cannot be ignored. Id. at 490 . And even though "some-perhaps a majority-" of the courts have always applied the rule, its cniorce- 
cedure, courts are required to find only that the Government's evidence standing alone is sufficient to support the deportation order, without necessarily considering the opposing evidence offered by the alien. ${ }^{45}$ Courts reviewing deportation orders under the APA as applied to the 1952 Act thus incur a "wider responsibility for reasonableness and fairness" 40 than is otherwise imposed. The limitations that many courts recognize on their scope of review in habeas corpus proceedings is eliminated. ${ }^{47}$

ment will still affect some courts. While the subject before the Court in the Universal Camera case was the rule of evidence applicable to NLRB findings, the Court carefully notes it is making a decision of universal application in defining the meaning of "substantial evidence . . . on . . . the whole record." Id. at 487.

45. In Estep v. United States, 327 U.S. 114, 122, 123 (1946) this minimal requircment was recognized. "The provisions making the decisions of the local [draft] boards 'final' means to us that Congress chose not to give administrative action under this act the customary scope of judicial review which obtains under other statutes. It means that the courts are not to weigh the evidence to determine whether the classification made by the local boards was justified." In a footnote the Court then pointed out: "That is the scope of judicial inquiry in deportation cases where Congress has made the orders of deportation final." Id. at 123 n.14.

Authorities differ, however, on whether, or to what extent, reviewing courts have actually ignored opposing evidence in reaching a conclusion on the validity of administrntive decisions. See Davis, Adninistrative Law 916, 917 (1951) and authorities cited therein.

46. Universal Camera Corp. v. National Labor Relations Board, 340 U.S. 474, 490 (1951).

47. While the change in the scope of review imposed by the APA may merely reflect what is the actual practice of some courts, and is perhaps an elusive one, sce notes 44 and 45 supra, it will act to ensure expansion of the review all courts afford deportation orders. See United States e.r rel. Lindenau v. Watkins, 73 F. Supp. 216 (S.D.N.Y. 1947) (the court recognizes a limitation in pre-APA habeas corpus review and compares it with the wider scope of review that is available to it under the APA); Yiakoumis v. Hall, 83 F. Supp. 469 (E.D. Va.), dismissed as moot, 177 F.2d 804 (4th Cir. 1949) (applicability of APA denied on ground that habeas corpus did not provide the broad revicw conttemplated by APA). The Heikkila court also recognized the more limited form of review in habeas corpus proceedings. Heikkila v. Barber, 73 Sup. Ct. 603, 606 (1953). And see the personal revelations made by Judge Simon Rifkind concerning the limitations on his authority to review Immigration officials' decisions in habeas corpus proceedings in Joint Hearings before the Committees on the Judiciary an S. 716, H.R. 237\%, and H.R. 2816, 82d Cong., 1st Sess. 575-6 (1951). Judge Rifkind referred particularly to an exclusion case, E.x parte Johnson, 82 F. Supp. 36 (S.D.N.Y.), aff'd sul nom. United States ex rel. Johnson v. Watkins, 170 F.2d 1009 (2d Cir. 1948), rev'd and rentanded sub nom. United States e.r rel. Johnson v. Shaughnessy, 336 U.S. 806 (1949); but his observations apply to deportation proceedings as well. The bills before Congress at the time of Judge Rifkind's testimony were the predecessors to the Immigration and Nationality Act of 1952. S.716 and H.R. 2379 provided that administrative decisions could bo reviewed only in habeas corpus proceedings on questions of law. The hearings contain an indictment of habeas corpus for the narrow scope of review it affords and the inconvenience it creates, and the witnesses before the Committees urge the application of $\$ 10$ of the Administrative Procedure Act. See Joint Hearings, sstpra, at 136 ct seq., 345 ct seq., 527 et seq., 575 et seq. Contra: id. at 711, 712. 
A further disadvantage to the alien restricted to habeas corpus review under the majority opinion in Hcikkila arises from the fact that the writ can be sought only when the alien has been taken into custody after service of the order of deportation. ${ }^{48}$ Under the APA, in contrast, judicial review of all pertinent issues is immediately available.40

The grave nature of deportation proceedings should prompt every consideration for the interests of alien deportees. ${ }^{50}$ The authority of Immigration officials is unlimited: they are charged with the duty of conducting investigations, holding hearings, prosecuting, and passing judgment. ${ }^{51}$ This commingling of judicial and enforcement functions in the same individuals has been deemed dangerous and open to abuse,

48. Yanish v. Phelan, 86 F. Supp. 461, 462 (N.D. Cal. 1949); Unitcd States cx rcl. Trinler v. Carusi, 166 F.2d 457, 461, zacated on other grounds, 168 F.2d 1014 (3d Cir. 1948). See, however, Slavick v. Miller, $\$ 9$ F. Supp. 575 (W.D. Pa.), of 'd, $1 \$ 4$ F.21 575 (3d Cir. 1950), cert. denicd, 340 U.S. 955 (1951) (detainer lodged for delivery ci alien to Immigration authorities at the end of his prison sentence; held: technical custody sufficient to authorize application for writ of habeas corpus to challenge deportation order).

49. Custody is not a prerequisite to review in other than habeas corpus procedings. The only prerequisite to judicial review of agency actions in the forms of review made available by the APA is the exhaustion of administrative remedies. See note 11 supra; Slavik v. Miller, stipra note 48.

A jurisdictional problem arises, however, where review is suught under the Administrstive Procedure Act. Habeas corpus proceedings can only be brought in the district in which the alien is detained, Ahrens v. Clark, 335 U.S. 1 SS (194N), and the Dircetor of Immigration and Naturalization for that district is the sole indispensable party. Mcdalha v. Shaughnessy, 102 F. Supp. 950 (S.D.N.Y. 1951). But where review is sought under the APA there is a division of opinion over whether the Commissioner of Immigration and Naturalization is an indispensable farty. Some courts have held that he is. Sie Paolo v. Garfinkel, 200 F.2d 280 (3d Cir. 1952) ; Podovinnikoff v. Miller, 179 Fi.2d 937 (3d Cir. 1950) ; Medalha v. Shaughnessy, supra; Birns v. Commissioner, 103 F. Supp. 180 (N.D. Ohio 1952). Others have held the other way. Sce Navarro v. Landon, 106 F. Supp. 73 (S.D. Cal. 1952); Yanish v. Phelan, 86 F. Supp. 401 (N.D. Cal. 1949); Yanish v. Wixon, 81 F. Supp. 499 (N.D. Cal. 1948), recid on other grousds sub rons. Yanish v. Barber, 181 F.2d 492 (9th Cir. 1950). For a discussion of this question, see Recent Developments in the Lan-Immigration and Nationality, 66 Hasv. L. REv. 643, 702-3 (1953).

50. While deportation is a civil proceeding-Bugajewitz v. Adams, 223 U.S. 385, 591 (1913) ; Bilokumsky v. Tod, 263 U.S. 149, 155 (1923), Mahler v. Eby, 264 U.S. 32, 39 (1924) -, the courts have recognized the gravity of the penalty it imposes. Sce Ng Fung Ho v. White, 259 U.S. 276, 234 (1922) (deportation is a proceeding capable of destroying "all that makes life worth living"); sec also Bridges v. Wixon, 320 U.S. 135, 147 (1945).

51. See note 4 supra. The Immigration and Naturalization Service has espresced dissatisfaction even with habeas corpus review, since it offers a means of delaying deportztion. Iarar. \& NAT. Serv. Ans. ReP. 10 (1952).

52. See the discussion in Rep. PeEsident's Coam. Inm. \& Nar. 154-67 (1953) and the references cited therein. See also the opinion of the Supreme Cuurt in Wong Yang Sung v. MicGrath, 339 U.S. 33, modified, 339 U.S. $\$ 0 \$$ (1950). The Court there held that the procedural requirements of the APA, 60 STIT. 241, 5 U.S.C. $\$ \$ 1004$, 104, 
personal freedom aspects of deportation cases. ${ }^{53}$ And the ability of deporta* tion officers to be objective and unerring in their judgment has been questioned. ${ }^{54}$ Thus the need for close judicial review of deportation orders is evident. Furthermore, it is unreasonable to compel deportees to terminate their affairs and submit to detention before it is finally determined that deportation is proper. $^{55}$ Against these arguments for APA review, the Justice Department half-heartedly asserted in the Heikkila case that such review might permit possibly repetitious litigation by granting a choice of remedies -declaratory judgment, injunction, and so on-to the deportee. The Government also argued that the deportee, under the Administrative Procedure Act, may be permitted to substitute venue in the District of Columbia for the district in which he is detained.50 These considerations, however, assume petty stature against the burdens and limitations of habeas corpus review. And for aliens whose rights and status are determined under the $1952 \mathrm{Act}$, Congress has clearly provided such opportunities.

While lower courts can avoid Heikkila to some extent by continuing to expand the scope of habeas corpus, equal treatment of all aliens seems a desirable legislative objective. Congress should therefore reconsider the plight of aliens excluded by Heikkila from the benefits of APA review, and

1007 (1946), were applicable to deportation proceedings. Thus, for a short time APA's remedial provisions obtained for such proceedings. But Congress was soon prevailed upon expressly to except deportation proceedings from the procedural requirements of the Act. 64 STat. 1048 (1950), 8 U.S.C. § 155(a) (Supp. 1952). See discussion of the arguments advanced for the exception by the Department of Justice in 98 CoNG. REc. 5625-6 (1952). Senator McCarran concedes that the arguments were fallacious. Ibid. See also the discussion of past attempts to take deportation proceedings out from under the APA. Ibid.

53. Wong Yang Sung v. McGrath, 339 U.S. 33, 46, modified, 339 U.S. 908 (1950). See Estep v. United States, 327 U.S. 114, 125 (1946) (concurrence of Justicc Murplyy suggesting that to accord finality to administrative decisions where personal liberties are involved is unconstitutional).

54. An arresting view is taken by Mr. Arthur Garfield Hays who writes: "[T] he judgment of the men in the [Immigration] Department is likely to be influenced by the fact that a decision favorable to the alien as a security risk might some day be subject to question or criticism, where nobody is subject to criticism if he is hard, cruel, casual, or uses bad judgment-that is if the individual is poor, unknown and helpless. The officer involved is patriotic-he takes no risk. Government officers are likely to become callous in the course of time. The Immigration Department has long been cruel and unfair." Hays, Introduction in Knaufs, The Ellen Knauff Story xii (1952). Sec United States ex rel. Knauff v. Shaughnessy, 338 U.S. 537, 551 (1950) (dissent by Justice Jackson). See also Rep. President's Comm. Ima. \& Nat. 162-3 (1953).

55. Though the harshness of continued custody is "normally" mitigated by the granting of bail, it is still an inconvenience to the alien that he cannot challenge the deportation order until he is taken into nominal custody. See statement of Robert L. Stcrin, Acting Solicitor General, speaking for himself and the Immigration and Naturalization Service, Hearings before the President's Comar. Imar. \& NAT. 1353 (1952).

56. Heikkila v. Barber, 73 Sup. Ct. 603,607 (1935). See also Brief for Respondent, pp. 44-46, Martinez v. Neelly, 73 Sup. Ct. 345 (1953). 
make Section 10 fully applicable to actions now pending under the 1917 Immigration Law.

More broadly, the whole question of deportation review might profitably be examined and remedial legislation enacted which strikes a balance between the alien's right to fair, efficient remedies and the Government's desire to obviate dilatory tactics. The President's Commission on Immigration and Naturalization has suggested such legislation. ${ }^{57}$ Its proposal would establish one definite proceeding for review, to be available within sixty days after the deportation order is issued, and to be brought in the district court of the district in which the alien is a resident. Such review would be granted priority on court calendars and the remedy sought would be made exclusive to prevent multitudinous attacks. The scope of the review would be governed by the provisions of the Administrative Procedure Act. An amendment of this sort is highly desirable. And to avoid decisions like Hcikkila, the new procedure should be made retroactive to cover those aliens now disadvantaged by the obsolete restrictions which historical development has made a part of the Immigration Act of 1917.

57. Rep. President's Coans. Imas. \& Nat. 169-70 (1953). 